\title{
肺の大細胞癌の術後遠隔成績に関する 臨床病理学的検討
}

Histological Features in Relation to the Results of the Surgical Treatment of Large Cell Carcinoma of the Lung 山下長司郎・坪田紀明・良河光一・河野富雄・神村和仁・千原久幸 石井 昇 - 中村和夫 - 高田佳木* · 大林加代子* - 岡田 聡**

要旨：術後大細胞癌と診断された 26 例 $(10.4 \%)$ を対象とした。P-TNM分類 I 期では 5 生率58 \%と比較的良好であったが，III，IV期では予後不良であった。予後と組織学的所見を検 討したところ, 腫瘍の発育様式, 巨細胞の出現頻度及び脈管侵襲像の 3 項目が予後と関 連をもつことが判明した。 即ち浸潤性発育を認めるもの, 高頻度に巨細胞の出現するも の及び著明な脈管侵襲を認めるものは予後を悪くする因子と考えられた.

〔肺癌 $24(6): 713 \sim 719,1984$ 〕

Key words : Large cell carcinoma of the lung, Invasive proliferation, Giant cells.

\section{緒 言}

肺の大細胞癌はその組織像が多彩で扁平上皮 癌や腺癌にみられるような細胞構築上の特徵に 乏しく，未だに不明な点が少くない，我々は過 去 9 年間における原発性肺癌切除例中, 大細胞 癌と診断された症例を昭和 57 年度の肺癌取扱い 規約にもとづいて再検討し, 組織学的所見と予 後に関して興味ある知見を得たので報告する。

\section{対象と方法}

昭和 48 年 4 月より昭和 57 年 3 月までの 9 年間 に神戸大学第 2 外科において手術をうけた原発 性肺癌249例のうち, 日本肺癌学会肺癌取扱い規 約に従った組織学的検索によって大細胞癌と診 断された26例 $(10.4 \%)$ を対象とした (Table 1).

神戸大学第 2 外科

$\begin{array}{lll}* & \text { 同 放射線科 } \\ * * & \text { 同 病理部 }\end{array}$

Table 1. Histologic distribution of 249 patients of lung cancer treated surgically over 10-years.

$1973 \sim 1982$

\begin{tabular}{lc} 
& cases \\
\hline Squamous cell ca. & 106 \\
Adenoca. & 92 \\
Large cell ca. & $26(10.4 \%)$ \\
Small cell ca. & 7 \\
others & 18 \\
\hline & 249 例
\end{tabular}

性別では男 23 例，女 3 例であった。年令は40才 代 4 例, 50 才代 6 例, 60 才代 9 例, 70 才代 6 例, 80 才代 1 例で平均年令は 63.4 才であった. 手術 は全例後側方開胸により行い, 胸壁浸潤例には 胸壁合併切除が行われた。縦隔リンパ節廓清に ついては, 縦隔肋膜を切開し触診にて検索し腫 
Fig. 1. Large cell carcinoma with non-invasive growth. Pseudomembrane was formed by normal lung tissue around the tumor. x 60 H-E stain

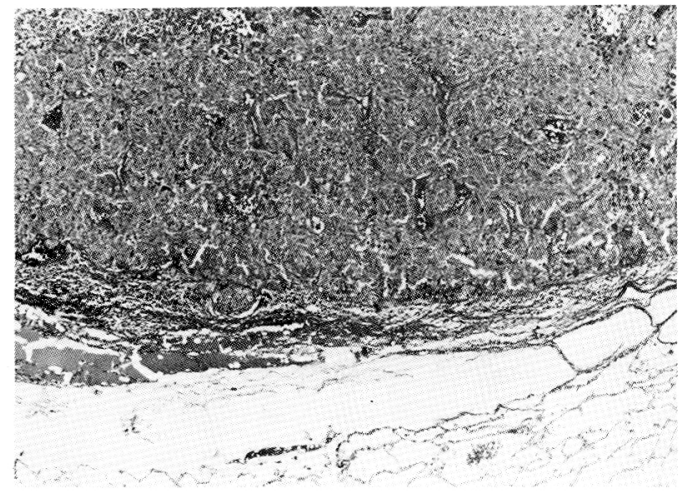

Fig. 2. Large cell carcinoma with invasive growth. Tumor cells infiltrate normal lung tissue.

x $60 \mathrm{H}-\mathrm{E}$ stain

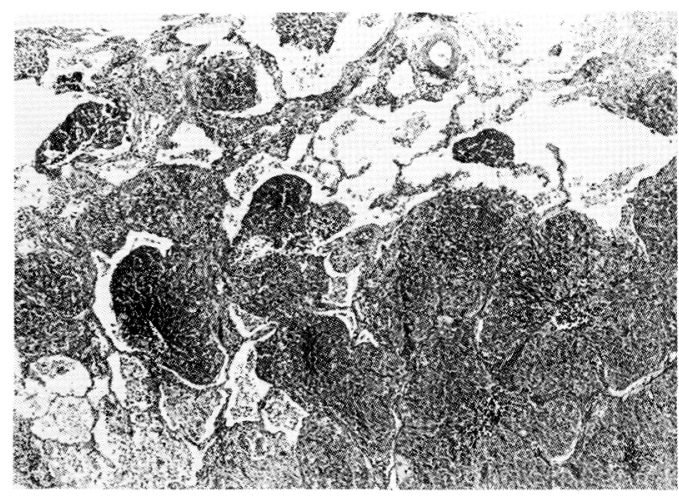

Fig. 3. Giant cells constitute more than $30 \%$ of tumor cells in all fields. x $290 \mathrm{H}$-E stain

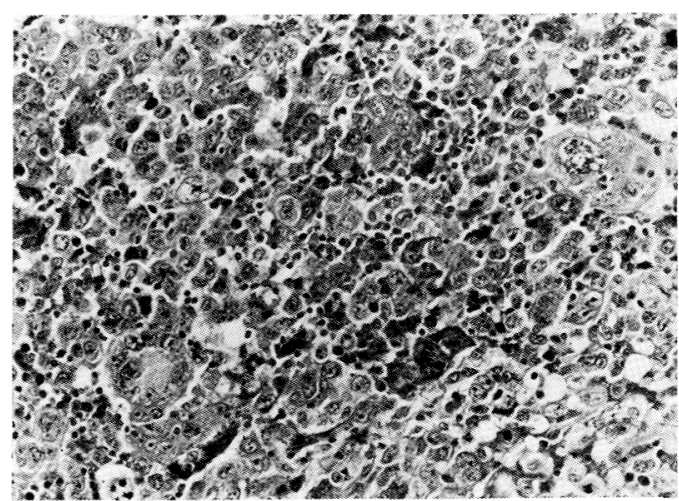

脹のみられるリンパ節を周囲脂肪組織を含めて 可及的に郭清した。術後は原則として, MMC, FTを中心とする化学療法を行い, 縦隔リンパ節 転移が著明であった症例には放射線療法を併用 した。生存率は生命表理論による累積生存率を 用いた。術後詳細な病理組織学的検索が可能て あったものは21例であるが，これらについて腫 瘍の発育様式，巨細胞の出現頻度，脈管侵襲の 程度, 粘液産生の有無, 間質の量, 壊死の範囲 等について検討した。発育様式については，圧 排性発育々浸潤性発育に分け, 腫瘍の辺縁部の 組織像で，腫瘍が肺組織を圧排するように発育 し，圧排された肺組織が偽性被膜化しているよ うな像を示すときこれを圧排性発育とした (Fig. 1).他方，腫瘍辺縁部で腫瘍細胞が肺胞壁 に沿って増生したり，西るいは肺胞腔内に増生 して，肺組織を腫瘍組織内に埋没吸収しつつ発 育増生している場合を浸潤性発育とした(Fig. 2)。同一標本内に圧排性発育と浸潤性の雨発育 様式が共存する場合には浸潤性発育が $30 \%$ 以上 に認められる時浸潤性発育とした。巨細胞の出 現頻度は，標本の全視野で巨細胞が癌細胞の30 \%以上を占好もを(\#)，それ以下のものを $(+)$ ，全く出現していないものを(一)として 3 段階に分類した (Fig. 3)。脈管侵襲像は癌細胞 の血管あるいはリンパ管内侵襲像の著明なもの を(+），わずかに散見されるものを(+)，確認 し得ないものを(一)とした。また，腫瘍細胞に 粘液が証明される場合を mucin $(+)$ とし, 粘液 が証明されない場合を $\operatorname{mucin}(-)$ として表示し た，間質の量は腫瘍組織内の間質成分が正常肺 胞壁の厚さより明らかに増生し且つ腫瘍組織の 過半数の領域にこれが認められる場合を $(+)$ と し，そうでない場合を(ー)として判定した。壊 死の範囲は腫瘍組織の壊死像が認められる場合 を(十)上し，壊死像が認められない場合を( として判定した。以上のごとき病理組織学的判 定基準で腫瘍組織を検索し，それぞれの項目に ついて病期及び予後上の関連を検討した。なお 病理組織標本は，腫瘍の最大径を含む割面で $\mathrm{H}-\mathrm{E}$ 染色標本を 3 枚以上作成し，必要に応じて PAS·AB重染色, Elastica van Gieson染色, 及 
び鍍銀染色標本を作成して検索した。

\section{結 果}

I) 手術成績. P-TNM分類では，I 期11例，II 期 3 例，III期 9 例，IV期 3 例と 26 例のうち $54 \%$ がI，II期の比較的早期の症例であった。これ らの症例に対して17例に葉切除， 5 例に肺剔除， 4 例に試験開胸が行われた。 1 例では左上葉切 除に胸壁合併切除が行われた，根治度別にみる と, 治癒切除 13 例, 準治癒切除 6 例, 非治癒切 除 3 例，試験開胸は 4 例であった (Table 2)。切 除標本及び胸部レントゲン写真より腫瘍発生部 位を推測すると，末梢型が18例 $(70 \%)$ と大部分 であり，肺門型はわずか 8 例であった. Fig. 4は 同時期における原発性肺癌の組織別生存曲線で あるが，大細胞癌の 5 生率は $30 \%$ あ゙あ，扁平 上皮癌と腺癌の中間にあった．Fig．5は大細胞 癌の Stage 別術後遠隔成績であるが, P-TNM I 期では 7 年以上生存の 2 例を含めた 5 年率は $58 \%$ と比較的良好であったが，III，IV期ではい ずれも 3 年生存例はなく，平均生存期間はIII期 で7.6力月, IV期で 3 力月と短く予後は不良であ った.

2)組織学的所見と予後 (Table 3) 6 項約の 組織学的所見のうち予後との関連性が認められ た項目は腫瘍の発育様式，巨細胞の出現頻度， 脈管侵襲像の 3 項目であり，粘液産生の有無, 間質の量，壊死の範囲などは関連がみられなか った。発育様式は21例のうち，圧排性発育を示 したのが10例，浸潤性発育を示したのが11例で あった，発育様式と術後病期及び予後との関連 を調べたところ，圧排性発育を示す10例のうち 7 例までが I， II 期の比較的早期例であり，生 存期間は 2 年〜 7 年 (平均 4 年) と良好であった。 浸潤性発育を示す 11 例では 5 例は I， II 期であ つたが，残りの 6 例はIII期の進行例であり，全 例 2 力月〜 1 年で死亡している. 巨細胞の出現 頻度が $30 \%$ 以上を占める 6 例は，圧排性発育例 にはみられず，全例浸潤性発育を示し，そのう ちの 4 例はIII期で 1 年以内に死亡している。著 明な脈管侵襲像を示した 6 例のうち 4 例はIII期 又はIV期であり 2 年以内に死亡し予後不良であ
Table 2. Post-operative stage and the type of operation of 26 large cell carcinoma cases.

\section{pTNM}

\begin{tabular}{lrlll} 
I & 11 & curative & 13 \\
II & 3 & semi curative & 6 \\
III & 9 & non curative & 3 \\
N & 3 & & non resectable & 4 \\
\cline { 2 - 3 } & 26 & & 26
\end{tabular}

Fig. 4. Survival by histologic cell type following resection. $(\mathrm{N}=224)$

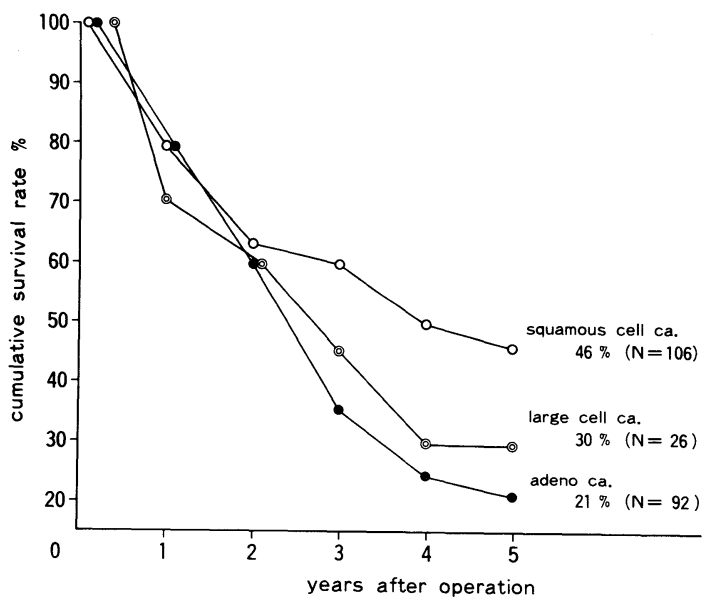

Fig. 5. Survival of large cell carcinoma following resection. $(\mathrm{N}=26)$

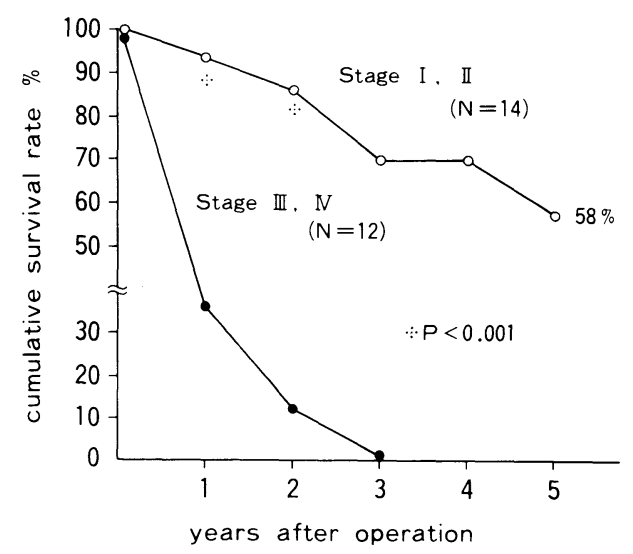


Table 3. Post-operative stages, radicality, histologic features and prognosis. Giant cell: $(++)$ more than $30 \% ;(+)$ less than 30\%; $(-)$ not found. Vascular invasion: $(++)$ prominent; $(+)$ moderate; $(-)$ not found. Mucin: $(+)$ present; $(-)$ not found. Stroma: $(+)$ more than thickness of normal alveolar wall and found in more than half of the tumor; $(-)$ less than thickness of normal alveolar wall and found in less than half of the tumor. Necrosis: $(+)$ present; (-) not found.

Non Invasive Growth

\begin{tabular}{|c|c|c|c|c|c|c|c|c|}
\hline Name & Stage & Radicality & $\begin{array}{l}\text { Giant } \\
\text { cell }\end{array}$ & $\begin{array}{l}\text { Vasc. } \\
\text { invasion }\end{array}$ & Mucin & Stroma & Necrosis & Prognosis \\
\hline 1. $B$ & I a & curative & + & + & + & - & - & $7 \mathrm{Y}$ alive \\
\hline 2. I & I a & curative & - & - & + & - & - & $5 \mathrm{Y}$ alive \\
\hline 3. $B$ & I a & semi-curat. & - & - & + & - & + & $3 y$ alive \\
\hline 4. $\mathrm{H}$ & I a & curative & + & + & - & + & + & $4 Y$ dead \\
\hline 5. $\mathrm{H}$ & I a & curative & - & + & - & - & + & $2 Y$ dead \\
\hline 6. $Y$ & I a & curative & + & - & + & + & + & $2 Y$ dead \\
\hline 7. $T$ & II & curative & - & - & + & - & - & $5 \mathrm{Y}$ alive \\
\hline 8. U & III & semi-curat. & + & $H$ & - & + & + & $2 Y$ dead \\
\hline 9. A & III & semi-curat. & - & - & - & - & - & 5 Mo dead \\
\hline 10. 0 & N & non-curat. & + & $H$ & - & - & - & 2 Mo dead \\
\hline
\end{tabular}

Invasive Growth

\begin{tabular}{|l|c|c|c|c|c|c|c|c|}
\hline 1. K & I a & curative & - & - & - & + & - & 9 Y alive \\
2. H & I a & curative & - & $H$ & - & - & - & $7 Y$ alive \\
3. T & I a & curative & $H$ & + & - & - & + & $3 Y$ alive \\
4. N & I a & curative & $H$ & - & + & + & - & 5 Mo dead \\
5. N & II & curative & - & $H$ & - & - & - & $3 Y$ dead \\
6. I & II & semi-curat. & $H$ & $H$ & + & - & - & $1 Y$ dead \\
7. Y & III & unresect. & - & - & + & - & - & $1 Y$ dead \\
8. M & III & non-curat. & $H$ & + & - & + & - & 9 Mo dead \\
9. M & II & semi-curat. & $H$ & + & - & - & + & 5 Mo dead \\
10. H & III & non-curat. & - & $H$ & + & + & + & 3 Mo dead \\
11. A & III & semi-curat. & $H$ & + & - & - & + & 2 Mo dead \\
\hline
\end{tabular}

Table 4. Correlation between histologic features and survival rate.

(\%)

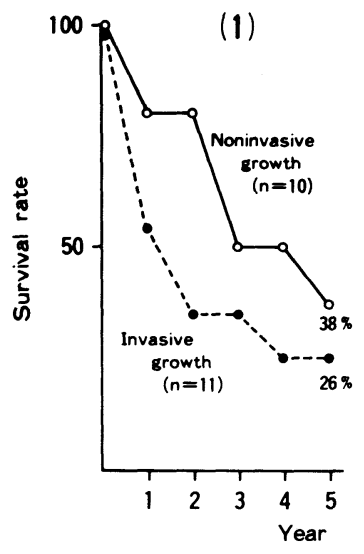

(\%)

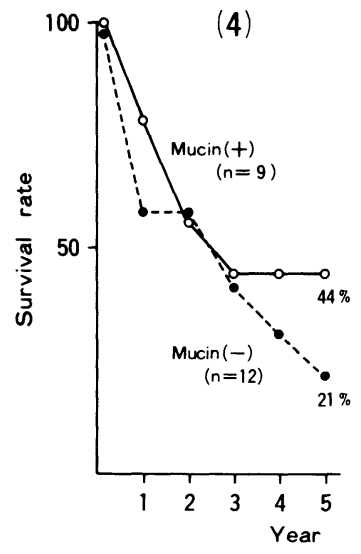

(\%)

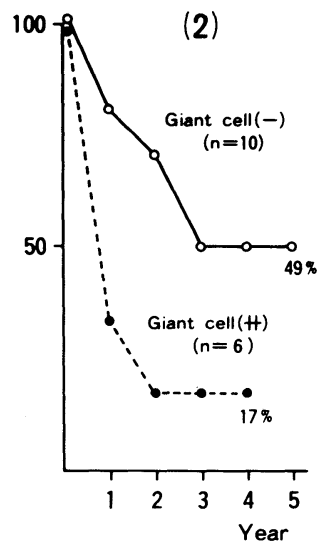

(\%)

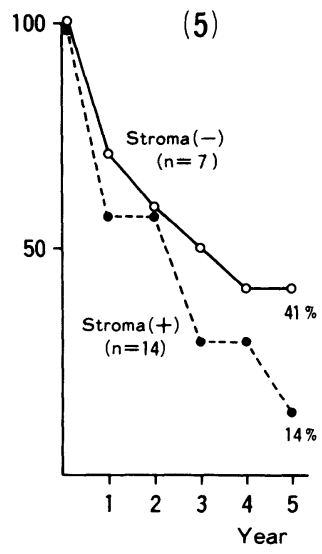

(\%)

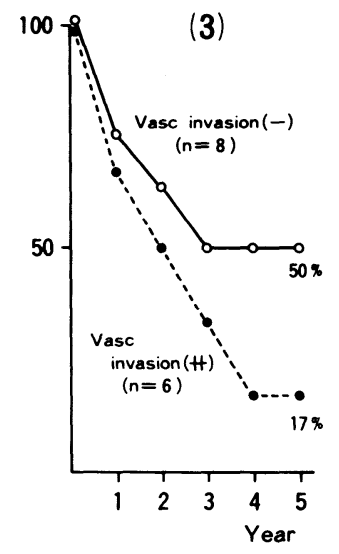

(\%)

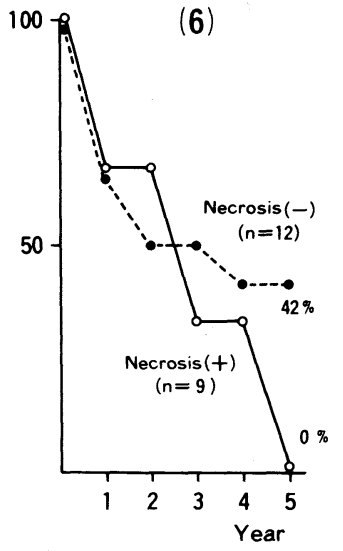


った. Table 4 は 6 項目別に生命表理論による生 存率を示したものである. 症例数が少いため推 計学的な処理はできなかったが, 発育様式, 巨 細胞の出現頻度, 脈管侵襲像の 3 項目では, 生 存率に差がある傾向を認めた。しかし, 粘液産 生の有無, 間質の量, 壊死の範囲などでは特に 差を認めなかった。

\section{考 察}

肺大細胞癌は扁平上皮癌や腺癌のような細胞 構築上の特徵がなく, 組織分類的には waste basket的な存在である。特に低分化扁平上皮癌 や低分化腺癌との区別はむずかしく, 診断に際 しては昭和57年度肺癌取扱い規約にもとづき, 角化のみられるもの, 管腔形成のあるもの, 細 胞管橋のあるもの等を全て除外したものを大細 胞癌としたが, 微細構造学的には扁平上皮癌や 腺癌の未分化なものであったとの報告もあり ${ }^{1)}$, 組織像で決定的な診断的特徵がないのが現状で ある. $01 \operatorname{cott}^{2)}$ のいうごとく, 大細胞癌は扁平上 皮癌または腺癌へ分化するMultipotentialityを 維持している未分化腫瘍細胞からなると考之る ならばこの事実も十分理解できる。ともあれ今 までに報告され大細胞癌の頻度は土井 ${ }^{3)}$ らの 6 \%より, Stanley ${ }^{4)} の 14 \%$, さらにPatton ${ }^{5} ら の$ 40\%までさまざまであるが，1982年の吉村6)ら による全国集計では7.6\%となっている.当科に おいては全手術例のうち $10.4 \%$ であったが, 先 に述べた様に大細胞癌の病理診断には除外診断 的な場合が多く, 未だ本症に関する特徵が発見 されていない現在では, 病理学者の主観や, 観 察される切片の部位などにより頻度に多少の巾 のあるのもやむを得ないものと思われる。さら に土井 ${ }^{3)}$ らは, 術前の細胞診と術後永久標本に よる組織型との一致率は, 扁平上皮癌や腺癌で は70\% 80\%であったのに較べ大細胞癌では 23 \%に過ぎなかったと述へ， 細胞診による診断の 困難性を述べている。

従来の報告では, 大細胞癌はその大部分が末 梢性に発生し, 発育速度及び縦隔への進展は速 く, かなり早期より血行性, リンパ行性に転移 しやすく予後不良の癌であるとされてきた。ま
た，木村7らの報告では，日本臨床病期分類の III, IV期が76\%を占め, 吉村6)らの全国集計でも

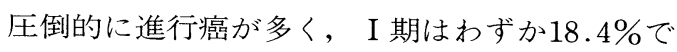
あったと述べているが，我々の施設では，26例 中11例 (42\%) がP-TNM分類のI 期であり比較 的早期の症例が多かった. 又荒井 ${ }^{8)}$ ち 110 例中 45例 (40.9\%), 土井3) ら は43例中 21 例 (49\%) が I 期であったと報告している。このような頻度 の違いは著者らの施設が手術を対象とするのに 対し，木村らは放射線治療を主とする施設であ ることにこのような病期の違いがあらわれたの であろう。しかし吉村 ${ }^{6)}$ のいう如く, 全肺癌症例 のうち約 $50 \%$ がIII，IV期であり，全体的にみれ ばやはり III, IV期の進行例が多いものと推察さ れる。

手術成績は当然のことながらP-TNM分類 I 期の 5 生率はよく, 土井 ${ }^{3)}$ は $75 \%$, Williams ${ }^{9} 66$ $\%$, 荒井 ${ }^{8} 49.9 \%$, 著者らは $58 \%$ と比較的良好な 成績であり，我々の施設では同時期における扁 平上皮癌 $78 \%$ と腺癌 $40 \%$ の中間にあった。しか L III, IV期の成績は悪く, 化学療法, 放射線療 法, 免疫療法などの集学的治療に反応せず 3 年 生存例はみられなかった。

扁平上皮癌, 腺癌などにおいては，その組織 像と予後との関連を述べた論文が散見されるが, 大細胞癌に関する報告は少い。下里 ${ }^{10)}$ らは大細 胞癌は単純な構造を示しているものの, 癌化後 もMultipotentialityをわずかながらも保持して いる細胞からなると考之るなら, 扁平上皮癌や 腺癌への分化の方向, 程度に従って子後が異な ってくるのも当然であろうと述べている，又最 近Mayer ${ }^{11)}$ らは層構造を持った腫瘍は層構造を 持たないものに較べ予後は良好であったと述べ ている，予後を決定する因子には癌の組織型, 進行度に加之て, 癌の発生部位, 発育形態及び 発育速度が関与していると考えられるが, 我々 は今回発育様式に注目し検討を加之た。奥野 ${ }^{12}$ は大細胞癌は扁平上皮癌と同様に肺胞充実性な いし圧排性に発育し, 肉眼的にも辺縁は鮮明で 小結節が集合した如くみ之, 光顕的にも腫痬と 肺組織は明瞭に境されていると述べているが, 我々の症例では肉眼的には圧排性でも顕微鏡的 
には浸潤性のことがあり，両者の所見は必ずし も一致しなかった。そこで我々は組織学的に発 育様式を浸潤性発育と圧排性発育に分け，病期 や予後との関連を調べたところ，浸潤性発育例 は，圧排性発育例に較べP-TNM分類のIII期が 多く，それらの予後は不良であった。そこで両 者の腫瘍の発生部位及び発見動機について検討 してみたところ，浸潤性発育，圧排性発育とも に末梢型が多く見られ両者間に差はなかった。 発見動機でも，咳，胸痛などの自覚症状及び集 検頻度における両者の差はなく，浸潤性発育を 示すものは圧排性発育を示すものに較べ発育速 度が速いのではないかと推察された。発育様式 と大細胞癌の特徵である巨細胞の出現頻度及び 脈管侵襲像との関連をしらべたところ, 巨細胞 が30\%以上出現した症例は全て浸潤性発育例で あり，圧排性発育例には認められなかった。建 石 $^{13)}$ ら, 多核巨細胞, Cytophagocytosis, Uninuclear giant cellなどの組織学的特徵をも
つものを巨細胞癌とし, 発育速度が速く, 生存 期間が平均 7 力月で非常に予後不良であると述 べているが，巨細胞型大細胞癌と同一のもので あるかは明らかではない。

以上のことより，大細胞癌の中でも浸潤性発 育を示すものは，圧排性発育例よりも発育速度 が速く，30\%以上の巨細胞の出現，著明な脈管 侵襲像と相まって子後を悪くする因子と考えら れた。

\section{まとめ}

1)大細胞癌の術後成績は，P-TNM I 期では 5 生率 $58 \%$ と良好であったが，III，IV期では子 後不良であった。

2) 予後と組織学的所見を検討したところ，浸 潤性発育を認女るもの，腫瘍細胞中に $30 \%$ 以上 の巨細胞が出現するもの，著明な脈管侵襲を認 めるものは子後を悪くする因子と考えられた。

\section{文}

1) Churge, A. : The fine structure of large cell undiffererentiated carcinoma of the lung. Hum. Pathol., 9 : 143, 1978.

2) Olcot, C.T.: Cell types and histologic patterns in carcinoma of the lung. Am. J. Pathol., $31: 975,1955$.

3）土井 修, 鍋島秀雄, 岡本信洋, 他: 肺癌の組 織型と外科療法. 手術, 35：6，651-665, 1981.

4) Stanley, K.E., Patthews, M.J., : Analysis of a pathology view of patients lung tumors. J. National cancer institute. 66:6, 989-992, 1981.

5) Patton, M., et al. : Blonchogenic large cell carcinoma. J. Thorac. Cardiovasc. Surge., $22: 88-94,1951$.

6）吉村克俊，山下延男：全国集計 $(1975 \cdot 76 \cdot 77$ 年 次)よりみた大細胞癌一日本TNM肺癌委員会 報告一肺癌, $22 ： 3 ， 336 ， 1982$.

7）木村 誠, 中島信明, 早川和重, 他：肺の大細

胞癌に関する臨床的および組織学的検討．肺 癌, $21: 1,1-7,1981$.

8）荒井他嘉司，秋山三郎，安藤喜八，他：国療肺 癌研究会における肺大細胞癌切除例の臨床的 検討. 肺癌, $22 ： 3 ， 336,1982$.

9) Williams, D.E., et al. : Survival of patients surgically treated for stage I lung cancer. J. Thorac. Cardiovasc. Surge., 82 : 70-76, 1981.

10）下里幸雄：“悪性腫瘍の病理”現代外科学大系30 巻 C，肺気管支III，P.51，中山書店，1969.

11) Mayer J.E., et al. : Influence of histologic type on survival after curative resection for undifferentiated lung cancer. J. Thorac. Cardiovasc. Surg., 84 :5, 641-647, 1982.

12) 奥野武彦：肺癌の胸部レントゲン像と組織型と の関連. 肺癌, $15 ： 2,89-104,1975$.

13）建石竜平，松田 実，寺沢敏夫，他：肺の巨細 胞癌の臨床病理学的研究. 癌の臨床, $15: 7$, 603-614, 1969. 


\title{
Histological Features in Relation to the Results of the Surgical Treatment of Large Cell Carcinoma of the Lung
}

Chojiro Yamashita, M.D., Noriaki Tsubota, M.D., Koichi Yoshikawa, M.D., Tomio Kono, M.D., Kazuhiro Kamimura, M.D., Hisayuki Chihara, M.D., Noboru Ishii, M.D., Kazuo Nakamura, M.,D., Yoshiki Takata, M.D. *, Kayoko Obayashi, M.D. *, and Satoshi Okada, M.D.**

\author{
Department of Thoracic and Cardiovascular Surgery, Kobe University \\ School of Medicine \\ * Department of Radiology \\ ** Department of Pathology
}

From 1973 through 1982, a total of 249 patients with lung cancer were operated on and $26(10.6 \%)$ were diagnosed as large cell carcinoma histologically.

The 5-year survival rate of large cell carcinoma was $50 \%$ in stage $\mathrm{I}$, but there were no patients who survived more than 3 years in stages III and IV. The relation between survival rate and histologic features was discussed.

Most large cell carcinomas which showed invasive growth, frequent appearance of giant cells and vascular invasion were operated on in advanced stages, and it was concluded that these three histological features should be considered as factors indicating poor prognosis. 